\title{
PEMANFAATAN LIMBAH SABUT KELAPA MENJADI POT BUNGA UNTUK MENUNJANG PEREKONOMIAN WARGA DESA PENGALIHAN DIERA PANDEMI COVID'19
}

\section{Eliah Siregar ${ }^{1}$}

${ }^{1}$ Jurusan Agroteknologi, Fakultas Pertanian, Universitas Islam Indragiri, Tembilahan

Email: eliahsiregar@gmail.com

\section{Abstract}

The main producer of the Pengalihan Village community is from coconut plantations, what the community produces from coconut plantations is only round coconut, white copra and shell charcoal, but currently the selling price of coconut has decreased slightly so that it affects people's income. The utilization of by-products of coconut plants is very large, one of which is from coconut coir. Utilization of coconut coir waste is very effective and can be an alternative option to support the economy of the Pengalihan Village community in the Covid19 Pandemic Era. Coconut coir waste is one of the easily obtained biomass and is a byproduct of agriculture. Coconut coir waste has great potential as flower pots because it contains cellulose which in its molecular structure contains a carboxyl group and lignin which contains phenolic acid which is needed for plants.

Keywords: coconut, coir waste, flower pot, covid'19.

\begin{abstract}
Abstrak
Penghasil utama masyarakat Desa Pengalihan adalah dari perkebunan kelapa, yang dihasilkan masyarakat dari perkebunan kelapa hanyalah kelapa bulatan, kopra putih dan arang tempurung namun saat ini nilai jual harga kelapa sedikit menurun sehingga berpengaruh pada pendapatan masyarakat. Pemanfaatan hasil samping tanaman kelapa sangat besar peluangnya salah satunya adalah dari sabut kelapa. Pemanfaatan limbah sabut kelapa sangatlah efektif dan dapat menjadi salah satu pilihan alternatif untuk menunjang perekonomian masyarakat Desa Pengalihan Diera Pandemi Covid'19. Limbah Sabut kelapa adalah salah satu biomassa yang mudah didapatkan dan merupakan hasil samping pertanian. Limbah sabut kelapa sangat berpotensi sebagai Pot Bunga karena mengandung selulosa yang di dalam struktur molekulnya mengandung gugus karboksil serta lignin yang mengandung asam phenolat yang dibutuhkan bagi tanaman.
\end{abstract}

Kata kunci: kelapa, sabut kelapa, covid'19.

\section{PENDAhUluan}

Secara administratif Desa Pengalihan berada dalam wilayah Kecamatan Enok, Kabupaten Indragiri Hilir, Provinsi Riau dengan luas Desa 3115 Ha dan penghasil utama masyarakat Desa Pengalihan adalah bertani. Pada awal 2020, dunia dikejutkan dengan mewabahnya pneumonia baru yang bermula dari Wuhan (China) yang kemudian menyebar dengan cepat ke lebih dari 190 negara dan teritori. Wabah ini diberi nama Coronavirus Disease 2019 (COVID'19) yang disebabkan oleh Severe Acute Respiratory Syndrome Corona Virus-2 (SARS-CoV-2). Penyebaran penyakit ini telah memberikan dampak luas secara sosial dan ekonomi (Adityo Susilo dkk,2020).

Pandemi Covid'19 juga sangat berpengaruh terhadap perekonomian warga Desa Pengalihan Kecamatan Enok. Di Era Pandemi Covid'19 ini kegiatan masyarakat dibatasi sehingga berpengaruh terhadap perekonomian masyarakat, ditambah lagi penghasil utama masyarakat Desa Pengalihan adalah dari perkebunan kelapa, yang dihasilkan masyarakat dari perkebunan kelapa hanyalah kelapa bulatan, kopra putih dan arang tempurung namun saat ini nilai jual harga kelapa sedikit menurun sehingga berpengaruh pada pendapatan masyarakat. 


\begin{tabular}{|l|l|c|l|}
\hline No & \multicolumn{3}{|c|}{ Data Kabupaten } \\
\hline 1 & Nama Desa/Kelurahan & $:$ & Pengalihan \\
\hline 2 & Kecamatan & $:$ & Enok \\
\hline 3 & Kabupaten & $:$ & $\begin{array}{l}\text { Indragiri } \\
\text { Hilir }\end{array}$ \\
\hline 4 & Provinsi & $:$ & Riau \\
\hline 5 & Luas Desa / Kelurahan & & $3115 \mathrm{Ha}$ \\
\hline 6 & $\begin{array}{l}\text { Jarak Ke Ibukota } \\
\text { Kecamatan }\end{array}$ & $:$ & 14,3 \\
\hline 7 & $\begin{array}{l}\text { Jarak Ke } \\
\text { Ibukota } \\
\text { Kabupaten }\end{array}$ & $\begin{array}{l}\text { Jarak Ke } \\
\text { Ibukota } \\
\text { Provinsi }\end{array}$ & $\begin{array}{l}\text { KM } \\
\text { KM }\end{array}$ \\
\hline 8 & & & \\
KM & & \\
\end{tabular}

atkan produk primernya saja, baik dalam bentuk kelapa segar maupun kopra untuk bahan baku minyak goreng. Pengembangan dan pemanfaatan produk hilir kelapa belum banyak dilakukan, demikian pula pemanfataan hasil samping dan limbah. Upaya pengembangan produk dan pemanfaatan hasil samping dan limbah akan meningkatkan nilai tambah produk kelapa yang pada gilirannya akan dapat meningkatkan pendapatan petani kelapa 2018).

(Dirjenbun, 2012 dalam Mira Ariyanti

Pemanfaatan hasil samping tanaman kelapa sangat besar peluangnya salah satunya adalah dari sabut kelapa. Pemanfaatan limbah sabut kelapa sangatlah efektif dan dapat menjadi salah satu pilihan alternatif untuk menunjang perekonomian masyarakat Desa Pengalihan Diera Pandemi Covid'19.

Limbah sabut kelapa bisa dimanfaatkan menjadi hasil karya yang begitu indah dan bermanfaat untuk kehidupan sehari-hari, yang bisa dihasilkan dari limbah sabut kelapa salah satunya adalah menjadi pot bunga yang berbahan dasar dari sabut kelapa. Selain proses pembuatan dan pendapatan bahan yang mudah, nilai jual pasar juga cukup mahal dan mampu menghasilkan nilai seni yang sangat indah

\section{TINJAUAN PUSTAKA}

\subsection{Profil Desa Pengalihan}

Desa Pengalihan adalah salah satu Desa yang terletak di Kecamatan Enok, Kabupaten Indragiri Hilir, Provinsi Riau. Desa pengalihan memiliki luas sekitar 3115 ha dengan pengahasil utama masyarakat adalah bertani, dan komoditi utama pertanian desa pengalihan adalah dari perkebunan kelapa.
1. Tabel Data Kecamatan Enok Sumber: Data Kecamatan Enok

\begin{tabular}{|l|l|}
\hline \multicolumn{2}{|c|}{ Luas wilayah } \\
\hline $\begin{array}{l}\text { Pekarangan/ } \\
\text { angunan }\end{array}$ & $50 \mathrm{Ha}$ \\
\hline Pasilitas Umum & $2,1 \mathrm{Ha}$ \\
\hline Perkebunan & $3065 \mathrm{Ha}$ \\
\hline Perikanan & \\
\hline ana / pasang surut & \\
\hline Hutan & \\
\hline
\end{tabular}

2, Tabel Luas Daerah atau Wilayah

Sumber: Data Kecamatan Luas Wilayah Enok

3, Tabel Batas Wilayah

\begin{tabular}{|l|l|l|l|}
\hline 1 & Utara & $:$ & Desa Jaya Bakti \\
\hline 2 & Selatan & $:$ & Desa Bagan Jaya \\
\hline 3 & Barat & $:$ & Desa Sungai Rukam \\
\hline 4 & Timur & $:$ & Desa Sungai Ambat \\
\hline
\end{tabular}

Sumber: Data Batas Wilayah Kecamatan Enok

4, Tabel Jumlah Penduduk

\begin{tabular}{|c|c|c|c|}
\hline No & \multicolumn{3}{|c|}{ Jumlah Penduduk } \\
\hline 1 & $\begin{array}{ll}\text { Jumlah } & \text { Kepala } \\
\text { Keluarga } & \\
\end{array}$ & $:$ & $814 \mathrm{KK}$ \\
\hline 2 & $\begin{array}{ll}\text { Jumlah } & \text { Penduduk } \\
\text { laki-laki } & \end{array}$ & : & $\begin{array}{l}1628 \\
\text { JIWA }\end{array}$ \\
\hline 3 & $\begin{array}{l}\text { Jumlah Penduduk } \\
\text { Perempuan }\end{array}$ & : & $\begin{array}{l}1762 \\
\text { JIWA }\end{array}$ \\
\hline 4 & Penduduk & $:$ & $\begin{array}{l}3390 \\
\text { JIWA }\end{array}$ \\
\hline
\end{tabular}

Sumber: Data Jumlah Penduduk

5, Tabel Mata Pencaharian

\begin{tabular}{|l|l|c|l|}
\hline No & \multicolumn{3}{|c|}{ Mata Pencaharian } \\
\hline 1 & Petani Buruh & $:$ & 505 Jiwa \\
\hline 2 & $\begin{array}{l}\text { Nelayan Jiwa } \\
\text { Tani/Buruh }\end{array}$ & $:$ & 21 Jiwa \\
\hline 3 & Nelayan & $:$ & 30 Jiwa \\
\hline 4 & Buruh Pabrik & $:$ & 50 Jiwa \\
\hline 5 & Pedagang & $:$ & 33 Jiwa \\
\hline 6 & Pengusaha sedang & $:$ & 50 Jiwa \\
\hline 7 & Guru Honor & $:$ & 56 Jiwa \\
\hline 8 & $\begin{array}{l}\text { Pegawai Negeri Sipil } \\
\text { PNS ) }\end{array}$ \\
\hline
\end{tabular}

Sumber: Data Mata Pencaharian

6, Tabel Penduduk Menurut Agama

\begin{tabular}{|l|l|c|l|}
\hline No & \multicolumn{3}{|c|}{ Penduduk Menurut Agama } \\
\hline 1 & Islam & $:$ & $\begin{array}{l}3374 \\
\text { Jiwa }\end{array}$ \\
\hline 2 & Budha & $:$ & 16 Jiwa \\
\hline 3 & Hindu & $:$ & \\
\hline 4 & Kristen katolik & $:$ & \\
\hline 5 & Kristen protestan & $:$ & \\
\hline
\end{tabular}


Sumber: Penduduk Menurut Agama

7. Tabel Fasilitas Keagamaan

\begin{tabular}{|l|l|c|l|}
\hline No & \multicolumn{3}{|c|}{ Fasilitas Keagamaan } \\
\hline 1 & Mesjid & $:$ & 3 Unit \\
\hline 2 & Mushola/Surau/Langgar & $:$ & 8 Unit \\
\hline 3 & Pura & $:$ & \\
\hline 4 & Gereja & $:$ & \\
\hline
\end{tabular}

Sumber: Data Fasilitas Keagamaan Kecamatan Enok

\section{8, Kelembagaan Organisasi}

\begin{tabular}{|l|l|c|l|}
\hline No & \multicolumn{3}{|c|}{ Kelembagaan Organisasi } \\
\hline 1 & $\begin{array}{l}\text { Badan } \\
\text { Permusyawaratan Desa } \\
\text { (BPD ) }\end{array}$ & $:$ & 1 Badan \\
\hline 2 & $\begin{array}{l}\text { Lembaga } \\
\text { Pemberdayaan } \\
\text { Masyarakat }\end{array}$ & $:$ & 1 Lembaga \\
\hline 3 & PKK & $:$ & 1 Organisasi \\
\hline 4 & Majlis Taqlim & $:$ & 6 Kelompok \\
\hline 5 & Pemuda & $:$ & 1 Organisasi \\
\hline 6 & Karang Taruna & $;$ & 1 \\
\hline
\end{tabular}

Sumber: Data Kelembagaan Organisasi

\section{9, Tabel Tingkat Pendidikan}

\begin{tabular}{|l|c|l|}
\hline Tidak tamat SD & $:$ & 1333 Jiwa \\
\hline SD / Sederajat & $:$ & 793 Jiwa \\
\hline SLTP / Sederajat & $:$ & 370 Jiwa \\
\hline SLTA / Sederajat & $:$ & 403 Jiwa \\
\hline Akademi / Perguruan Tinggi & $:$ & 125 Jiwa \\
\hline Buta Huruf & $:$ & 426 Jiwa \\
\hline
\end{tabular}

\subsection{Kelapa}

Kelapa ialah tanaman tropis yang sudah usang dikenal masyarakat Indonesia, hal ini terlihat berasal penyebarannya hampir pada semua daerah Nusantara (Dirjenbun, 2012 dalam Mira Ariyanti dkk, 2018). tanaman kelapa merupakan tanaman sosial sebab lebih $98 \%$ diusahakan oleh petani sehingga perkebunan kelapa banyak didominasi perkebunan masyarakat dibandingkan perkebunan negara ataupun swasta (Dewan Kelapa Indonesia, 2014 dalam Mira Ariyanti dkk, 2018).

Pada taksonomi tumbuh-tumbuhan, tanaman kelapa dimasukkan ke dalam klasifikasi menjadi berikut:

$\begin{array}{lll}\text { Kingdom } & : \text { Plantae } \\ \text { Sub Kingdom } & : \text { Viridiplantae } \\ \text { Infra Kingdom } & : \text { Streptophyta } \\ \text { Super Divisi } & : \text { Embryophyta }\end{array}$

Divisi

Sub Divisi

Kelas

Super Ordo

Ordo

Keluarga

Genus

Spesies

Tracheophyta
Spermatophytina
Magnoliopsida
Lilianae
Arecales
Arecaceae
Cocos L.
Cocos nucifera L

Selama ini komoditas kelapa hanya dimanfaatkan produk primernya saja, baik pada bentuk kelapa segar maupun kopra untuk bahan standar minyak goreng. Pengembangan serta pemanfaatan produk hilir kelapa belum banyak dilakukan, demikian juga pemanfataan yang akan terjadi samping dan limbah. Upaya pengembangan produk dan pemanfaatan akibat samping dan limbah akan mempertinggi nilai tambah produk kelapa yg dapat meningkatkan pendapatan petani kelapa (Dirjenbun, 2012 dalam Mira Ariyanti 2018).

Pemanfaatan akibat samping tanaman kelapa sangat akbar peluangnya salah satunya adalah asal sabut kelapa. Pemanfaatan limbah sabut kelapa sangatlah efektif dan dapat sebagai galat satu pilihan cara lain buat menunjang perekonomian rakyat Desa Pengalihan Diera Pandemi Covid'19.

Limbah Sabut kelapa ialah galat satu biomassa yg simpel dihasilkan dan adalah akibat samping pertanian. Komposisi sabut pada buah kelapa kurang lebih 35\% berasal berat holistik butir kelapa. Sabut kelapa terdiri dari serat (fiber) dan gabus (pitch) yg menghubungkan satu serat dengan serat yg lainnya. Sabut kelapa terdiri asal 75\% serat serta $25 \%$ gabus (Carrijo,dkk.2002).

Limbah sabut kelapa sangat berpotensi menjadi Pot Bunga karena mengandung selulosa yg di dalam struktur molekulnya mengandung gugus karboksil serta lignin yang mengandung asam phenolat yang diharapkan bagi tumbuhan (Pino,dkk.2005).

\subsection{Corona Virus}

Corona Virus Disease - 19 (Covid'19) kini menjadi pandemi yang sangat serius dan berbahaya di seluruh penjuru dunia karena telah merenggut ribuan nyawa. Pencegahan meluasnya virus corona kini telah menjadi prioritas utama di beberapa negara, termasuk Indonesia. Segala kegiatan yang mengundang keramaian, kerumunan, dan interaksi sudah mulai di blokade, Warga negara kini diwajibkan untuk \&quot;stay at home\&quot; sebagai salah 
satu bentuk upaya pencegahan penularan virus corona.

Covid'19 adalah penyakit menular yang disebabkan oleh jenis coronavirus yang baru ditemukan. Ini merupakan virus baru dan penyakit yang sebelumnya tidak dikenal sebelum terjadi wabah di Wuhan, Tiongkok, bulan Desember 2019. Penyakit yang disebabkan infeksi Covid'19 pada umumnya bersifat ringan, terutama pada anak-anak dan orang dewasa muda. Namun, infeksi ini tetap dapat menyebabkan penyakit serius (I Nyoman Artayasa 2021).

Sejak kasus pertama di Wuhan, terjadi peningkatan kasus Covid'19 di China setiap hari dan memuncak diantara akhir Januari hingga awal Februari 2020. Awalnya kebanyakan laporan datang dari Hubei dan provinsi di sekitar, kemudian bertambah hingga ke provinsi-provinsi lain dan seluruh China bahkan tersebar ke Indonesia (Adityo Susilo dkk,2020).

Pencegahan virus corona bisa dimulai dari diri sendiri. Salah satu yang bisa dilakukan adalah mengetahui informasi terbaru tentang pandemi Covid-19 yang tersedia di situs WHO dan melalui otoritas kesehatan publik. Saran WHO untuk kita semua agar dapat menghindari diri dari infeksi virus novel Covid-19 dengan menjaga kesehatan Anda dan lindungi orang lain. Salah satunya dengan menggunakan masker, menjaga jarak, melakukan cuci tangan dan menggunakan handsanitizer (Kharismatul Khasanah dkk, 2021).

\section{METODOLOGI PENELITIAN}

\subsection{Waktu dan tempat penelitian} Penelitian ini dilaksanakan dilokasi Desa Pengalihan, Kecamatan Enok, Kabupaten Indragiri Hilir, Provinsi Riau pada tanggal 05 Agustus 2021 sampai dengan 23 September 2021.

\subsection{Alat dan Bahan Penelitian}

Alat dan bahan yang digunakan pada penelitian ini yaitu Kawat Jaring, 2 meter, Serat Sabut Kelapa, Gunting, Penggaris, dan alat dokumentasi.

\subsection{Cara Kerja Penelitian}

Pada awal penelitian dilakukan penyortiran bahan baku pembuatan pot bunga yaitu limbah sabut kelapa.
Selanjutnya dilakukan penjemuran serat sabut kelapa agar kering. Setelah itu Langkah selanjutnya adalah pembuata pot bunga dari limbah sabut kelapa. Teknik pembuatannya adalah sebagai berikut :

1. Suwir bagian serat sabut kelapa menjadi halus,

2. Potong kawat jaring menjadi 4 bagian dengan ukuran bagian 1 Panjang $30 \mathrm{~cm}$ Lebar $17 \mathrm{~cm}$ untuk lapisan dalam, bagian 2 Panjang $50 \mathrm{~cm}$ lebar $15 \mathrm{~cm}$ lapisan luar, bagian 3 panjang $15 \mathrm{~cm}$ lebar $15 \mathrm{~cm}$ alas lapisan dalam, bagian 4 panjang $20 \mathrm{~cm}$ lebar $20 \mathrm{~cm}$ alas lapisan luar,

3. Selanjutnya buat berbentuk tabung untuk bagian 1 lapisan dalam dan bagian 2 lapisan luar seperti digambar,

4. Selanjutnya potong bagian 3 dan 4 sesuai lebar lingkaran untuk alas bagian lapisan luar dan dalam (bagian 1 dan 2),

5. Selanjutnya masukkan sabut yang telah dihaluskan tadi memenuhi alas dan lapisan, masukkan dan padatkan,

6. Setelah penuh dan padat rapikan dan tutup bagian atas kawat lapisan dalam membalik keluar

\section{HASIL DAN PEMBAHASAN}

Dalam penelitian ini dipelajari cara atau teknik dalam pembuatan pot bunga yang ramah lingkungan dengan berbahan dasar dari limbah sabut kelapa. Pemanfaatan sabut kelapa dapat menjadi pot bunga dapat mengurai limbah pertanian yang ada, selain itu juga pembuatan pot bunga dengan berbahan dasar sabut kelapa memiliki daya tarik tersendiri dengan keindahan seni.

Sabut kelapa memiliki serat-serat yang mempu mengikat air sehingga sangat baik dijadikan pot bunga ataupun tanaman lainnya, terbukti karena sabut kelapa memiliki beberapa kandungan unsure hara yang dibutuhkan bagi tanaman.

\subsection{Analisis Serap Air}

Berdasarkan hasil penelitian didapatkan bahwa semakin tebal dan rapat susunan serat sabut kelapa dalam 
pembuatan pot bunga maka semakin kuat pot bunga tersebut dalam mengikat air.

Begitu juga sebaliknya semakin tipis kandungan serat dalam pembuatan pot bunga makan semakin sedikit dalam mengikat air.

\subsection{Analisis Ketahanan Pot Bunga}

Uji kekuatan kualitas pot dilakukan dengan menarik bagian-bagian pot dan juga membanting pot yang telah dibuat. Berdasarkan hasil penelitian yang dilakukan didapatkan bahwa semakin rapat pengikatan antar kawat maka semakin kuat kualitas pot bunga tersebut.

Dalam penelitian ini dipelajari cara atau teknik dalam pembuatan pot bunga yang ramah lingkungan dengan berbahan dasar dari limbah sabut kelapa. Pemanfaatan sabut kelapa dapat menjadi pot bunga dapat mengurai limbah pertanian yang ada, selain itu juga pembuatan pot bunga dengan berbahan dasar sabut kelapa memiliki daya tarik tersendiri dengan keindahan seni.

Sabut kelapa memiliki serat-serat yang mempu mengikat air sehingga sangat baik dijadikan pot bunga ataupun tanaman lainnya, terbukti karena sabut kelapa memiliki beberapa kandungan unsure hara yang dibutuhkan bagi tanaman.

\section{KESIMPULAN DAN SARAN}

\section{Kesimpulan}

Desa Pengalihan Kecamatan Enok memiliki potensi besar di sektor pertanian yang membantu perekonomian warga Desa Pengalihan yaitu perkebunan kelapa. Namun, di era pandemi covid'19 ini warga Desa Pengalihan mengalami kesulitan dalam perekonomian akibat dari tidak stabilnya harga kelapa ditambah kegiatan warga dalam menunjang perekonomian yang lain kini dibatasi. Oleh karena itu peneliti beserta rekan-rekan Mahasiswa Kuliah Kerja NyataTematik Universitas Islam Indragiri Tahun 2021 Desa Pengalihan Melakukan Observasi serta berusaha membantu memecahkan masalah yang terjadi saat ini ditengah masyarakat.

Peneliti menyarankan, serta mengajak warga desa pengalihan untuk memanfaatkan potensi yang ada didesa pengalihan yaitu dengan Pemanfaatan Limbah Sabut Kelapa menjadi Pot Bunga Untuk Membantu Menunjang Perekonomian Warga Desa Pengalihan di Era Pandemi Covid'19 ini.

Saran

Peneliti berharap kedepannya

Pemerintah Desa bersama masyarakat Desa Pengalihan bisa memaksimalkan Limbah Kelapa tersebut menjadi pot bunga untuk membantu menunjang perekonomian Masyarakat Desa Pengalihan melalui penguatan Kelembagaan Desa.

\section{DAFTAR PUSTAKA}

1. Ariyanti, Mira, Dkk. 2018. Pertumbuhan Tanaman Kelapa (Cocos Nucifera L.) Dengan Pemberian Air Kelapa. Jurnal Harian Pertanian.

2. Artayasa, I Nyoman. 2021. Kebijakan Pemerintah Dalam Percepatan Penanganan Dampak Covid 19 Di Kota Denpasar. Jurnal Cakrawati.

3. Muh Amin, St, Mt, Dkk. 2010. Pemanfaatan Limbah Serat Sabut Kelapa Sebagai Bahan Pembuat Helm Pengendara Kendaraan Roda Dua. Jurnal Google Scholar.

4. Pascawati, Dkk. 2010. Pemanfaatan Sabut Kelapa Sebagai Bahan Baku Pembuatan Kertas Komposit Alternatif. Jurnal Widya Teknik.

5. Siregar, Eliah. 2020. Pembuatan Pot Bunga dari Limbah Sabut Kelapa. Sumber Youtube. https://youtu.be/60vERqG5vRE

6. Sunardi, Dkk. 2019. Pemanfaatan Limbah Air Dan Sabut Kelapa Untuk Peningkatan Kesejahteraan Masyarakat Mojosari. Jurnal Universitas Muhammadiyah Jakarta

7. Susilo, Adityo, Dkk. 2020. Coronavirus Disease 2019 Tinjauan Literatur Terkini. Jurnal Penyakit Dalam Indonesia 